\title{
Tanggung Jawab dan Perlindungan Hukum bagi Notaris secara Perdata Terhadap Akta yang Dibuatnya
}

\author{
Kunni Afifah \\ Magister Kenotariatan fakultas Hukum Univeristas Islam Indonesia \\ Jl. Cik Di Tiro No. 1 Yogyakarta \\ kunnia@yahoo.com
}

\begin{abstract}
This study examines the form of liability and legal protection in civil Notary on the deeds made. This law research is empirical juridical kind. The results of this study indicate that a civil liability of a Notary who committed an unlawful act is the Notary shall account for his actions with civil sanctions in the form of reimbursement or compensation to the injured party on an unlawful act committed by a Notary. But before Notary sanctioned civil then Notary must first be proven that there has been any loss arising out of a tort Notary against the parties, and between the losses and the tort of Notaries are causal relationships, and tort or negligence due to an error that can be accounted to the Notary concerned. While the form of legal protection for Notary on the deeds which made related to civil liability Notary is the Honorary Council of notaries who are independent, in this case the existence of MKN not a sub part of the government who appointed him.
\end{abstract}

Keywords: Notary, responsibility in the civil protection law

\begin{abstract}
Abstrak
Penelitian ini mengkaji bentuk pertanggungjawaban dan perlindungan hukum bagi Notaris secara perdata terhadap akta-akta yang dibuatnya. Jenis penelitian hukum ini adalah jenis penelitian yuridis empiris. Hasil penelitian ini menunjukkan bahwa pertanggungjawaban secara perdata seorang Notaris yang melakukan perbuatan melawan hukum adalah Notaris wajib mempertanggungjawabkan perbuatannya dengan dijatuhi sanksi perdata berupa penggantian biaya atau ganti rugi kepada pihak yang dirugikan atas perbuatan melawan hukum yang dilakukan oleh Notaris. Namun sebelum Notaris dijatuhi sanksi perdata maka Notaris terlebih dahulu harus dapat dibuktikan bahwa telah adanya kerugian yang ditimbulkan dari perbuatan melawan hukum Notaris terhadap para pihak, dan antara kerugian yang diderita dan perbuatan melawan hukum dari Notaris terdapat hubungan kausal, serta perbuatan melawan hukum atau kelalaian tersebut disebabkan kesalahan yang dapat dipertanggungjawabkan kepada Notaris yang bersangkutan. Sedangkan bentuk perlindungan hukum bagi Notaris terhadap akta-akta yang dibuatnya terkait pertanggungjawaban Notaris secara perdata adalah adanya Majelis Kehormatan Notaris yang bersifat independen, dalam hal ini keberadaan MKN tidak merupakan sub bagian dari pemerintah yang mengangkatnya.
\end{abstract}

Kata-kata kunci : Notaris, tanggung jawab secara perdata, perlindungan hukum. 


\section{Pendahuluan}

Jabatan Notaris lahir karena masyarakat membutuhkannya, bukan jabatan yang sengaja diciptakan kemudian baru disosialisaikan kepada khlayak. Jabatan Notaris ini tidak ditempatkan di lembaga yudikatif, eksekutif ataupun yudikatif karena Notaris diharapkan memiliki posisi netral. Jabatan Notaris diadakan atau kehadirannya dikehendaki oleh aturan hukum dengan maksud untuk membantu dan melayani masyarakat yang membutuhkan alat bukti tertulis yang bersifat otentik mengenai keadaan, peristiwa atau perbuatan hukum.

Saat ini Undang-Undang Nomor 30 Tahun 2004 tentang Jabatan Notaris telah diperbaharui dengan Undang-Undang Nomor 2 Tahun 2014 tentang Jabatan Notaris (selanjutnya disebut UUJNP). Pengertian Notaris sebagaimana dimaksud dalam Pasal 1 angka 1 UUJNP adalah Pejabat umum yang berwenang untuk membuat akta otentik dan memiliki kewenangan lainnya sebagaimana dimaksud dalam undang-undang ini atau berdasarkan undang-undang lainnya.

Kedudukan Notaris sebagai Pejabat umum, dalam arti kewenangan yang ada pada Notaris tidak pernah diberikan kepada pejabat-pejabat lainnya, selama sepanjang kewenangan tersebut tidak menjadi kewenangan pejabat-pejabat lain. Sesuai dengan ketentuan tersebut, maka Notaris adalah satu-satunya pejabat yang berwenang untuk membuat akta otentik mengenai semua perbuatan, perjanjian, dan penetapan yang diharuskan oleh suatu peraturan umum atau oleh yang berkepentingan dikehendaki untuk dinyatakan dalam suatu akta otentik, semuanya sepanjang pembuatan akta itu oleh suatu peraturan umum tidak juga ditugaskan atau dikecualikan kepada pejabat atau orang lain.

Pejabat lain yang diberikan kewenangan membuat akta otentik selain Notaris, antara lain: ${ }^{1}$ 1. Consul (berdasarkan Conculair Wet); 2. Bupati Kepala Daerah atau Sekretaris Daerah yang ditetapkan oleh Menteri Kehakiman; 3. Notaris Pengganti; 4. Juru Sita pada Pengadilan Negeri; 5. Pegawai Kantor Catatan Sipil.

Meskipun pejabat ini hanya menjalankan fungsi sebagai Pejabat umum akan tetapi mereka itu bukan Pejabat umum. Mengenai otentisitas suatu akta Notaris, lebih lanjut Soegondo Notodisoerjo, menyatakan: bahwa untuk dapat membuat akta otentik, seseorang harus mempunyai kedudukan sebagai "Pejabat umum". Di Indonesia, seorang advokat, meskipun ia seorang ahli dalam bidang hukum, tidak berwenang untuk membuat akta otentik, karena ia tidak mempunyai kedudukan sebagai "Pejabat umum". Sebaliknya seorang "Pegawai Catatan Sipil" (Ambtenaar van de Burgerlijke Stand) meskipun ia bukan

${ }^{1}$ H. Budi Untung, Visi Global Notaris, Andi, Yogyakarta, 2002, hlm. 43-44. 
ahli hukum, ia berhak membuat akta-akta otentik untuk hal-hal tertentu, umpamanya untuk membuat akta kelahiran, akta perkawinan, akta kematian. Demikian itu karena ia oleh undang-undang ditetapkan sebagai "Pejabat umum" dan diberi wewenang untuk membuat akta-akta itu. $^{2}$

Sesuai dengan kewenangannya, seorang Notaris berwenang untuk membuat akta otentik yang diatur dalam Pasal 15 ayat (1), (2) dan (3) Undang-Undang Nomor 2 Tahun 2014, antara lain sebagai berikut:

(1) Notaris berwenang membuat Akta autentik mengenai semua perbuatan, perjanjian, dan penetapan yang diharuskan oleh peraturan perundang-undangan dan/atau yang dikehendaki oleh yang berkepentingan untuk dinyatakan dalam Akta autentik, menjamin kepastian tanggal pembuatan Akta, menyimpan Akta, memberikan grosse, salinan dan kutipan Akta, semuanya itu sepanjang pembuatan Akta itu tidak juga ditugaskan atau dikecualikan kepada pejabat lain atau orang lain yang ditetapkan oleh undang-undang.

(2) Selain kewenangan sebagaimana dimaksud pada ayat (1), Notaris berwenang pula:

a. mengesahkan tanda tangan dan menetapkan kepastian tanggal surat di bawah tangan dengan mendaftar dalam buku khusus;

b. membukukan surat di bawah tangan dengan mendaftar dalam buku khusus;

c. membuat kopi dari asli surat di bawah tangan berupa salinan yang memuat uraian sebagaimana ditulis dan digambarkan dalam surat yang bersangkutan;

d. melakukan pengesahan kecocokan fotokopi dengan surat aslinya;

e. memberikan penyuluhan hukum sehubungan dengan pembuatan Akta;

f. membuat Akta yang berkaitan dengan pertanahan; atau

g. membuat Akta risalah lelang.

(3) Selain kewenangan sebagaimana dimaksud pada ayat (1) dan ayat (2), Notaris mempunyai kewenangan lain yang diatur dalam peraturan perundang-undangan.

Akta otentik yang dimaksud sebagai kewenangan Notaris dibuat dihadapan atau dibuat oleh Notaris berguna bagi masyarakat yang membutuhkan akta seperti akta pendirian Perseroan Terbatas, akta wasiat, surat kuasa, dan lain sebagainya. Kehadiran Notaris sebagai pejabat publik merupakan jawaban dari kebutuhan masyarakat akan kepastian hukum atas setiap perikatan yang dilakukannya, terutama perikatan terkait perdagangan dan kehidupan sehari-hari.

Perjanjian-perjanjian tertulis yang dibuat oleh atau dihadapan Notaris disebut dengan akta. Menurut Pasal 1 angka 7 UUJNP menentukan bahwa: "Akta Notaris adalah akta autentik yang dibuat oleh atau di hadapan Notaris menurut bentuk dan tata cara yang ditetapkan dalam undang-undang ini”. hlm. 43 .

${ }^{2}$ Kartini Soedjendro, Perjanjian Peraihan Hak atas Tanah yang Berpotensi Konflik, Kanisius, Yogyakarta, 2001, 
Akta otentik yang dimaksud adalah akta otentik sesuai dengan rumusan Pasal 1868 Kitab Undang Undang Hukum Perdata (untuk selanjutnya disebut KUHPerdata), yaitu: "Suatu akta otentik ialah akta yang didalam bentuk yang ditentukan oleh undang undang, dibuat oleh atau dihadapan pegawai pegawai umum yangberkuasa untuk itu di tempat dimana akta itu dibuat."

Tujuan dibuatnya perjanjian-perjanjian tertulis dihadapan atau dibuat oleh Notaris adalah agar akta tersebut menjadi akta otentik yang dapat digunakan sebagai bukti kuat jika suatu saat terjadi perselisihan antara para pihak atau ada gugatan dari pihak lain.

Akta otentik memberikan bukti yang mengikat dan sempurna terhadap para pihak (beserta para ahli waris mereka) atau mereka yang memperoleh hak dari para pihak itu, hal ini sesuai dengan ketentuan Pasal 1870 KUHPerdata yang berbunyi sebagai berikut: "Suatu akta untuk memberikan diantara para pihak beserta ahli warisnya atau orang-orang yang mendapat hak ini dari mereka, suatu bukti yang sempurna tentang apa yang dimuat didalamnya".

Kekuatan yang melekat pada akta otentik yaitu sempurna (volledig bewijskracht) dan Mengikat (bindende bewijskracht), yang berarti apabila alat bukti Akta Otentik diajukan memenuhi syarat formil dan materil dan bukti lawan yang dikemukakan tergugat tidak mengurangi keberadaanya, pada dirinya sekaligus melekat kekuatan pembuktian yang sempurna dan mengikat (volledig en bindende bewijskracht), dengan demikian kebenaran isi dan pernyataan yang tercantum didalamnya menjadi sempurna dan mengikat kepada para pihak mengenai apa yang disebut dalam akta. Sempurna dan mengikat kepada hakim sehingga hakim harus menjadikannya sebagai dasar fakta yang sempurna dan cukup untuk mengambil putusan atas penyelesaian perkara yang disengketakan. ${ }^{3}$

Terhadap akta-akta yang dibuat, Notaris wajib menyimpan dalam kumpulan dokumen yang terjilid berdasarkan nomor akta yang disebut minuta akta, sedangkan yang dikeluarkan untuk para pihak dalam akta tersebut berupa salinan akta yang sama persis bunyinya dengan minuta akta yang disimpan dikantor Notaris. Perbedaan antara minuta akta dengan salinan akta terletak diakhir akta, dalam minuta akta terdapat tandatangan para pihak saksi-saksi dan Notaris, sedangkan dalam salinan akta pada akhir akta hanya terdapat tandatangan Notaris saja

Akta Notaris yang tersimpan dalam minuta akta atau protokol Notaris, termasuk salah satu dokumen arsip negara yang harus disimpan dalam jangka waktu yang lama serta

${ }^{3}$ Christin Sasauw, “Tinjauan Yuridis Tentang Kekuatan Mengikat Suatu Akta Notaris”, Jurnal Lex Privatum, Vol. III/No. 1, 2015, hlm. 100. 
terjaga kerahasiaannya. Penyimpanan akta atau/ dokumen diatur dalam UUJNP Pasal 1 angka 13 yang berbunyi: "Protokol Notaris adalah kumpulan dokumen yang merupakan arsip Negara yang harus disimpan dan dipelihara oleh Notaris sesuai dengan ketentuan peraturan perundang-undangan."

Sebagai Pejabat umum (openbaar ambtenaar) Notaris berwenang membuat akta otentik. Sehubungan dengan kewenangannya tersebut Notaris dapat dibebani tanggung jawab atas perbuatannya/pekerjaannya dalam membuat akta oetentik. Tanggung jawab Notaris sebagai Pejabat umum meliputi tanggung jawab profesi Notaris itu sendiri yang berhubungan dengan akta. Sehubungan dengan kewenangannya tersebut Notaris dapat dibebani tanggung jawab atas perbuatannya/pekerjaannya dalam membuat akta oetentik. Tanggung jawab Notaris sebagai Pejabat umum meliputi tanggung jawab profesi Notaris itu sendiri yang berhubungan dengan akta, diantaranya: Pertama, Tanggung jawab Notaris secara perdata atas akta yang dibuatnya.Tanggung jawab dalam hal ini adalah tanggung jawab terhadap kebenaran materiil akta, dalam konstruksi perbuatan melawan hukum. Perbuatan melawan hukum disini dalam sifat aktif maupun pasif. Aktif, dalam artian melakukan perbuatan yang menimbulkan kerugian pada pihak lain. Sedangkan pasif, dalam artian tidak melakukan perbuatan yang merupakan keharusan, sehingga pihak lain menderita kerugian. Jadi unsur dari perbuatan melawan hukum disini yaitu adanya perbuatan melawan hukum, adanya kesalahan dan adanya kerugian yang ditimbulkan. Kedua, Tanggung jawab Notaris secara pidana atas akta yang dibuatnya. Pidana dalam hal ini adalah perbuatan pidana yang dilakukan oleh seorang Notaris dalam kapasitasnya sebagai Pejabat umum yang berwenang membuat akta, bukan dalam konteks individu sebagai warga negara pada umumnya. Ketiga, Tanggung jawab Notaris secara administrasi atas akta yang dibuatnya. Sanksi administrasi bedasarkan Undang-Undang No. 2 Tahun 2014 menyebutkan ada 5 (lima) jenis sanksi administrasi yang diberikan apabila seorang Notaris melanggar ketentuan Undang-Undang Nomor 2 Tahun 2014, yaitu: a. Peringatan lisan; b. Peringatan tertulis; c. Pemberhentian sementara; d. Pemberhentian dengan hormat; dan e. Pemberhentian dengan tidak hormat.

Akta otentik yang dibuat oleh atau dihadapan Notaris dapat digunakan sebagai pembuktian dalam sebuah sengketa hukum yang digunakan sebagai alat bukti untuk mengingat kembali peristiwa-peristiwa yang telah terjadi, sehingga dapat digunakan untuk kepentingan pembuktian. 
Pasal 1866 KUHPerdata mengatakan bahwa bukti tulisan merupakan salah satu alat bukti tertulis. Demikian pula dalam Pasal 1867 KUHPerdata yang menetapkan bahwa: "Pembuktian dengan tulisan dilakukan denga tulisan-tulisan otentik maupun dengan tulisantulisan dibawah tangan."

Akta Notaris mempunyai kekuatan pembuktian yang sempurna dalam gugatan perkara perdata, namun apabila melanggar ketentuan tertentu, akan terdegradasi nilai pembuktiannya menjadi mempunyai kekuatan pembuktian sebagai akta di bawah tangan, Notaris yang terbukti melakukan kesalahan sehingga mengakibatkan akta yang dibuatnya hanya mempunyai kekuatan pembuktian sebagai akta di bawah tangan atau akta menjadi batal demi hukum, maka akan menimbulkan kerugian bagi pihak klien atau pihak lainnya. Oleh karena itu, Notaris dapat dimintakan pertanggungjawaban atas kesalahannya tersebut dan diwajibkan memberikan ganti rugi, biaya, dan bunga kepada para pihak yang menderita kerugian.

Pada praktiknya permasalahan mengenai degradasi akta otentik dapat terjadi karena kelalaian dan/atau kurang ketelitian/kecerobohan seorang Notaris sehingga mengakibatkan akta yang dibuatnya mengalami degradasi kekuatan pembuktian atau batal demi hukum. Permasalahan hukum tersebut dapat muncul pada saat itu, atau dapat muncul setelah beberapa tahun kemudian saat minuta akta telah disimpan dalam protokol Notaris lain. Permasalahan hukum seperti yang telah diuraikan di atas memungkinkan Notaris berurusan dengan pertanggungjawaban secara hukum secara perdata.

Putusan Pengadilan Negeri Bekasi No.113/PDT.G/2008/PN.BKS adalah salah satu contoh bahwa Notaris kurang teliti, karena pada saat pembuatan akta Notaris tidak melihat sertipikat asli dan yang surat-surat yang mendukungnya perjanjian jual beli, misalnya surat persetujuan suami istri, karena antara suami istri yang tidak melakukan perjanjian kawin harus mendapat persetujuan dari teman kawinnya. Jika Notaris kurang teliti pada saat membuat akta, akan banyak pihak yang akan dirugikan, terutama bagi pihak penggugat. Atas kerugian tersebut maka para tergugat tersebut termasuk Notaris didalamnya harus membayar ganti rugi kepada penggugat dan segala surat-surat yang diterbitkan oleh Notaris itu batal demi hukum.

Kedua belah pihak dalam kasus tersebut telah melakukan upaya penyelesaian melalui musyawarah namun tidak ada penyelesaiannya dan masalah inipun sampai juga di Pengadilan. Di dalam kasus ini akta-akta yang dibatalkan oleh pengadilan adalah akta Notaris dan surat-surat lain yang berhubungan dengan jual beli tersebut. 


\section{Rumusan Masalah}

Berdasarkan uraian yang dikemukakan dalam latar belakang tersebut, maka ada beberapa hal yang menjadi pokok permasalahan dalam penelitian ini, yaitu: pertama, bagaimanakah pertanggungjawaban Notaris secara perdata terhadap akta-akta yang dibuatnya? Kedua, bagaimanakah perlindungan hukum bagi Notaris terhadap akta-akta yang dibuatnya terkait pertanggungjawaban Notaris secara perdata?

\section{Metode Penelitian}

Penelitian ini menggunakan pendekatan yuridis normatif, dengan menggunakan hukum primer ${ }^{4}$ terutama mengenai peraturan perundang-undangan Undang-Undang Tentang Jabatan Notaris Dalam penelitian ini data dikumpulkan melalui studi terhadap dokumen dan studi kepustakaan. Penelitian terhadap bahan-bahan hukum sekunder ${ }^{5}$ yang berasal dari sumber kepustakaan berupa buku, artikel, dan wawancara sebagai pelengkap. Data-data tersebut akan dianalisis secara diskriptif kualitatif.

\section{Hasil Penelitian dan Pembahasan}

Tanggung jawab yang dimiliki oleh Notaris menganut prinsip tanggung jawab berdasarkan kesalahan (based on fault of liability), dalam pembuatan akta otentik, Notaris harus bertanggung jawab apabila atas akta yang dibuatnya terdapat kesalahan atau pelanggaran yang disengaja oleh Notaris. Sebaliknya apabila unsur kesalahan atau pelanggaran itu terjadi dari para pihak penghadap, maka sepanjang Notaris melaksanakan kewenangannya sesuai peraturan. Notaris bersangkutan tidak dapat diminta pertanggungjawabannya, karena Notaris hanya mencatat apa yang disampaikan oleh para pihak untuk dituangkan ke dalam akta. Keterangan palsu yang disampaikan oleh para pihak adalah menjadi tanggung jawab para pihak. ${ }^{6}$

Pertanggungjawaban Notaris secara perdata terhadap akta-akta yang dibuatnya, dapat dikatakan bahwa akta yang dibuat oleh Notaris berkaitan dengan masalah keperdataan yaitu mengenai perikatan yang dibuat oleh dua pihak atau lebih meskipun memungkinkan hlm. 134

${ }^{4}$ C.F.G. Sunaryati Hartono, Penelitian Hukum di Indonesia Pada Akbir Abad ke-20, Alumni, Bandung, 1994, ${ }^{5}$ Loc. Cit.

${ }^{6}$ Andi Mamminanga, Pelaksanaan Kewenangan Majelis Pengawas Notaris Daerah dalam Pelaksanaan Tugas Jabatan Notaris berdasarkan UUJN, Tesis, Fakultas Hukum Universitas Gajah Mada, Yogyakarta, 2008, hlm. 32. 
dibuat secara sepihak (sifatnya hanya menguatkan). Sifat dan asas yang dianut oleh hukum perikatan khususnya perikatan yang lahir karena perjanjian, bahwa undang-undang hanya mungkin dan boleh diubah atau diganti atau dinyatakan tidak berlaku, hanya oleh mereka yang membuatnya, maksudnya kesepakatan kedua belah pihak yang dituangkan dalam suatu akta otentik mengikat kedua belah pihak sebagaimana mengikatnya undang-undang.

Asnahwati H. Herwidi, S.H. mengatakan bahwa, ${ }^{7}$ pada dasarnya Notaris tidak bertanggung jawab terhadap isi akta yang dibuat di hadapannya karena mengenai isi dari akta tersebut merupakan kehendak dan kesepakatan yang diinginkan oleh para pihak. Notaris hanya menuangkan kesepakatan tersebut kedalam bentuk akta otentik sehingga dalam hal ini Notaris hanya bertanggung jawab terhadap bentuk formal akta otentik sebagaimana yang ditetapkan oleh undang-undang.

Peran Notaris disini hanya mencatat atau menuangkan suatu perbuatan hukum yang dilakukan oleh para pihak/penghadap ke dalam akta. Notaris hanya mengkonstatir apa yang terjadi, apa yang dilihat, dan dialaminya dari para pihak/penghadap tersebut berikut menyesuaikan syarat-syarat formil pembuatan akta otentik kemudian menuangkannya ke dalam akta. Notaris tidak diwajibkan untuk menyelidiki kebenaran isi materiil dari akta otentik tersebut. Hal ini mewajibkan Notaris untuk bersikap netral dan tidak memihak serta memberikan semacam nasihat hukum bagi klien yang meminta petunjuk hukum pada Notaris yang bersangkutan.

Rusiana Suryadi mengatakan bahwa $^{8}$ kecuali isi akta, setiap perbuatan yang dilakukan oleh Notaris dapat dimintakan pertanggung jawabannya apabila ada suatu pelanggaran yang dilakukannya dan perbuatan tersebut menimbulkan kerugian bagi para pihak. Notaris harus mempertanggung jawabkan atas kebenaran materiil suatu akta bila nasihat hukum yang diberikannya ternyata dikemudian hari merupakan suatu yang keliru.

Notaris sebagai pejabat pembuat akta otentik, jika terjadi kesalahan baik disengaja maupun karena kelalaiannya mengakibatkan orang lain (akibat dibuatnya akta) menderita kerugian, yang berarti Notaris telah melakukan perbuatan melanggar hukum. Jika suatu kesalahan yang dilakukan oleh Notaris dapat dibuktikan, maka Notaris dapat dikenakan sanksi berupa ancaman sebagaimana yang telah ditentukan oleh undang-undang. Sebagaimana yang dimaksud dalam Pasal 84 UUJN yang menetapkan bahwa "dapat

${ }^{7}$ Hasil wawancara dengan Asnahwati H. Herwidi, S.H. selaku Notaris/PPAT Kabupaten Sleman pada tanggal 10 Oktober 2016.

${ }^{8}$ Hasil wawancara dengan Rusiana Suryadi, S.H. selaku Notaris/PPAT Kabupaten Sleman pada tanggal 17 Oktober 2016. 
menjadi alasan bagi pihak yang menderita kerugian untuk menuntut penggantian biaya, ganti rugi dan bunga kepada Notaris".

Ganti rugi atas dasar perbuatan melanggar hukum di dalam hukum perdata diatur dalam Pasal 1365 KUH Perdata, yang menentukan: "Tiap perbuatan melanggar hukum yang membawa kerugian kepada orang lain, mewajibkan orang yang karena salahnya menerbitkan kerugian itu, menggantikan kerugian tersebut. Apabila memperhatikan ketentuan Pasal 1365 KUH Perdata diatas, di dalamnya terkandung unsur-unsur sebagai berikut: 1. Perbuatan yang melanggar hukum; 2. Harus ada kesalahan; 3. Harus ada kerugian yang ditimbulkan; 4.Adanya hubungan kausal antara perbuatan dan kerugian.

Pasal 41 UU perubahan atas UUJN menentukan adanya sanksi perdata, jika Notaris melakukan perbuatan melawan hukum atau pelanggaran terhadap Pasal 38, Pasal 39, dan Pasal 40 UU perubahan atas UUJN maka akta Notaris hanya akan mempunyai pembuktian sebagai akta di bawah tangan. Akibat dari akta Notaris yang seperti itu, maka dapat menjadi alasan bagi pihak yang menderita kerugian untuk menuntut penggantian biaya, ganti rugi dan bunga kepada Notaris.

Perihal kesalahan dalam perbuatan melanggar hukum, dalam hukum perdata tidak membedakan antara kesalahan yang ditimbulkan karena kesengajaan pelaku, melainkan juga karena kesalahan atau kurang hati-hatinya pelaku. Ketentuan ini sesuai dengan yang dikemukakan oleh Riduan Syahrani sebagai berikut: "tidak kurang hati-hati”. ${ }^{9}$ Notaris yang membuat akta ternyata tidak sesuai dengan wewenangnya dapat terjadi karena kesengajaan maupun karena kelalaiannya, yang berarti telah salah sehingga unsur harus ada kesalahan telah terpenuhi.

Sri Peni Nughrohowati, S.H. mengatakan bahwa, ${ }^{10}$ Notaris dapat dimintakan pertanggung jawabannya apabila terdapat unsur kesalahan yang dilakukannya dan perlu diadakannya pembuktian terhadap unsur-unsur kesalahan yang dibuat oleh Notaris tersebut, yaitu meliputi: 1. Hari, tanggal, bulan, dan tahun menghadap; 2. Waktu (pukul) menghadap; dan 3. Tanda tangan yang tercantum dalam minuta akta.

Akta Notaris yang batal demi hukum tidak dapat dimintakan untuk memberikan penggantian biaya, ganti rugi dan bunga. Penggantian biaya, ganti rugi dan bunga dapat digugat kepada Notaris dengan mendasarkan pada hubungan hukum Notaris dengan para

\footnotetext{
${ }^{9}$ Riduan Syahrani, Seluk Beluk dan Asas-Asas Hukum Perdata, Alumni, Bandung, 1998, hlm. 279.

${ }^{10}$ Hasil wawancara dengan Sri Peni Nughrohowati, S.H. selaku Notaris/PPAT Kabupaten Sleman pada tanggal 19 Oktober 2016.
} 
pihak yang menghdap Notaris.Apabila ada pihak yang merasa dirugikan dari akta yang dibuat oleh Notaris, maka yang bersangkutan dapat secara langsung mengajukan tuntutan secara perdata terhadap Notaris tersebut sehingga Notaris tersebut dapat bertanggung jawab secara perdata atas akta yang dibuatnya.Tuntutan penggantian biaya, ganti rugi dan bunga terhadap Notaris, tidak didasarkan pada kedudukan alat bukti yang berubah karena melanggar ketentuanketentuan tertentu dalam UUJN, tetapi didasarkan kepada hubungan hukum yang terjadi antara Notaris dan para pihak yang menghadap Notaris tersebut.Sekalipun Notaris tersebut telah purna bakti, Notaris tersebut tetap harus bertanggung jawab secara perdata terhadap akta yang pernah dibuatnya.

Perihal kerugian dalam perbuatan melanggar hukum secara perdata Notaris dapat dituntut untuk menggati kerugian-kerugian para pihak yang berupa kerugian materiil dan dapat pula berupa kerugian immaterial. Kerugian dalam bentuk materiil, yaitu kerugian yang jumlahnya dapat dihitung, sedangkan kerugian immaterial, jumlahnya tidak dapat dihitung, misalnya nama baiknya tercemar, mengakibatkan kematian. Dengan adanya akta yang dapat dibatalkan atau batal demi hukum, mengakibatkan timbulnya suatu kerugian, sehingga unsur harus ada kerugian telah terpenuhi. Gugatan ganti kerugian atas dasar perbuatan melanggar hukum apabila pelaku melakukan perbuatan yang memenuhi keseluruhan unsur Pasal 1365 KUHPerdata, mengenai siapa yang diwajibkan untuk membuktikan adanya perbuatan melanggar hukum.

Perlindungan hukum terhadap Notaris dalam menjalankan tugas dan wewenangnya demi terlaksananya fungsi pelayanan dan tercapainya kepastian hukum dalam memberikan pelayanan kepada masyarakat, telah diatur dan dituangkan dalam Pasal 66 UUJNP.

Sri Peni Nughrohowati, S.H. mengatakan bahwa, ${ }^{11}$ sebagaimana yang dimaksud dalam UUJNP. Akta otentik pada hakikatnya memuat kebenaran formal sesuai dengan apa yang diberitahukan para pihak kepada Notaris. Notaris mempunyai kewajiban menerapkan apa yang termuat dalam Akta Notaris sungguh-sungguh telah dimengerti dan sesuai dengan kehendak para pihak, yaitu dengan cara membacakannya, sehingga isi dari Akta Notaris menjadi jelas. Jadi, dengan demikian para pihak dapat menentukan dengan bebas untuk menyetujui atau tidak menyetujui isi Akta Notaris yang akan ditandatanganinya.

Akta otentik yang dibuat oleh Notaris tidak jarang dipermasalahkan oleh salah satu pihak atau oleh pihak lain karena dianggap merugikan kepentingannya, baik itu dengan tidak sesuainya bentuk akta, pengingkaran akan isi akta, tandatangan maupun kehadiran

11 Hasil wawancara dengan Sri Peni Nughrohowati, S.H. selaku Notaris/PPAT Kabupaten Sleman pada tanggal 19 Oktober 2016. 
pihak di hadapan Notaris, bahkan adanya dugaan dalam akta otentik tersebut ditemukan keterangan palsu. Berkaitan dengan perlindungan hukum Notaris terhadap akta-akta yang dibuatnya terkait pertanggungjawaban Notaris secara perdata, dengan adanya ketidak hatihatian dan kesungguhan yang dilakukan Notaris, sebenarnya Notaris telah membawa dirinya pada suatu perbuatan yang oleh undang-undang harus dipertanggungjawabkan. Jika suatu kesalahan yang dilakukan oleh Notaris dapat dibuktikan, maka Notaris dapat dikenakan sanksi berupa ancaman sebagaimana yang telah ditentukan oleh undang-undang.

Daru Purwoningsih mengatakan bahwa, ${ }^{12}$ pentingnya perlindungan hukum bagi Notaris adalah untuk: 1. Menjaga keluhuran harkat dan martabat jabatannya, termasuk ketika memberikan kesaksian dan berproses dalam pemeriksaan dan persidangan; 2. Merahasiakan keterangan akta guna menjaga kepentingan para pihak yang terkait didalam akta tersebut; 3. .Menjaga minuta atau surat-surat yang dilekatkan pada minuta akta, serta protokol Notaris dalam penyimpanannya.

Perlindungan hukum yang diberikan terhadap (Jabatan) Notaris diatur dalam Pasal 66 UUJNP. Pasal 66 UUJNP ini mengatur mengenai dibentuknya Majelis Kehormatan Notaris (selanjutnya disebut MKN) yang beranggotakan perwakilan Notaris, pemerintah dan akademisi, yang berfungsi sebagai lembaga perlindungan hukum bagi Jabatan Notaris terkait dengan akta yang dibuat oleh atau diahadapannya.

Keberadaan MKN ini, diharapkan dapat memberikan kontribusi hukum yang optimal bagi institusi Notaris dalam menjalankan tugasnya sebagai lembaga perlindungan hukum. Mengenai pengaturan tentang kedudukan serta bentuk perlindungan hukum dari MKN ini sebetulnya belum diatur secara tegas dalam UUJN maupun dalam bentuk peraturan perundang-undangan yang lain. ${ }^{13}$

Kedudukan MKN dalam memberikan suatu perlindungan hukum bagi Notaris merupakan suatu lembaga yang bersifat independen, karena dalam hal ini keberadaan MKN tidak merupakan sub bagian dari pemerintah yang mengangkatnya. MKN dalam menjalankan kewenangannya mengeluarkan suatu keputusan tidak dipengaruhi oleh pihak atau lembaga lainnya, sehingga dalam hal ini keputusan yang dihasilkan oleh MKN ini tidak dapat diganggu gugat. ${ }^{14}$

${ }^{12}$ Hasil wawancara dengan Daru Purwoningsih, S.H. selaku Notaris/PPAT Kabupaten Sleman pada tanggal 20 Oktober 2016.

${ }^{13}$ Irene Dwi Enggarwati, 2015, Pertanggungjawaban Pidana Dan Perlindungan Hukum Bagi Notaris Yang Diperiksa Oleh Penyidik Dalam Tindak Pidana Keterangan Palsu Pada Akta Otentik, Tesis, Magister Kenotariatan Fakultas Hukum Universitas Brawijaya, Malang, hlm. 17.

${ }^{14}$ Ibid., hlm. 18. 
Sri Peni Nughrohowati mengatakan bahwa, ${ }^{15}$ apabila akta yang dibuat dihadapan/oleh Notaris bermasalah oleh para pihak sendiri, maka hal tersebut menjadi urusan para pihak sendiri, Notaris tidak perlu dilibatkan,dan Notaris bukan pihak dalam akta. Notaris dapat dituntut bertanggungjawab secara perdata apabila para pihak melakukan pengingkaran: 1. Hari, tanggal, bulan, tahun menghadap; 2. Waktu, pukul menghadap; 3. Tanda-tangan yang tercantum dalam minuta; 4. Merasa tidak pernah menghadap; 5. Akta tidak ditanda-tangani didepan Notaris; 6. Akta tidak dibacakan; dan 7. Alasan lain berdasarkan formalitas akta.

Berdasarkan hal-hal tersebut diatas hendaknya para pihak, wajib membuktikannya. UUJNP menyatakan apabila ada Notaris yang diduga terlibat masalah hukum terkait dengan akta yang dibuat oleh atau dihadapannya, maka penyidik, penuntut umum, maupun hakim ketika memanggil Notaris tersebut, harus mendapatkan persetujuan terlebih dahulu dari MKN. Sebagaimana termuat dalam Pasal 66 ayat (1) UUJNP yaitu: Untuk kepentingan proses peradilan, penyidik, penuntut umum, atau hakim dengan persetujuan Majelis Kehormatan Notaris berwenang: a) mengambil fotokopi Minuta Akta dan/atau surat-surat yang dilekatkan pada Minuta Akta atau Protokol Notaris dalam penyimpanan Notaris; dan b) memanggil Notaris untuk hadir dalam pemeriksaan yang berkaitan dengan Akta atau Protokol Notaris yang berada dalam penyimpanan Notaris.

Berdasarkan ketentuan yang tercantum dalam Pasal 66 ayat (1) UUJN Perubahan tersebut dapat diketahui bahwa penyidik, penuntut umum maupun hakim hanya diperkenankan untuk mengambil: 1. Foto kopi minuta akta dan/atau surat-surat yang dilekatkan pada minuta akta atau protokol Notaris dalam penyimpanan Notaris; 2. Penyidik, penuntut umum, maupun hakin, tidak diperkenankan atau tidak dibenarkan mengambil minuta akta dan/atau surat-surat asli yangndilekatkan pada minuta akta atau protokol Notaris dalam penyimpanan Notaris.

Pemanggilan Notaris oleh penyidik, penuntut umum, maupun hakim untuk hadir dalam pemeriksaan suatu perkara perdata harus memerlukan persetujuan dari MKN, karena pada saat ini MKN merupakan lembaga perlindungan hukum bagi Notaris, apabila nanti ada Notaris yang diduga melakukan kesalahan atau pelanggaran dalam hal pembuatan akta. Dengan demikian akan lebih terjamin apabila segala tindakan pemanggilan, pemeriksaan dan penahanan itu dilakukan setelah ada izin dari organisasi profesi yang memeriksanya

${ }^{15}$ Hasil wawancara dengan Sri Peni Nughrohowati, S.H. selaku Notaris/PPAT Kabupaten Sleman pada tanggal 19 Oktober 2016. 
terlebih dahulu, sehingga pada akhirnya akan tercipta kepastian hukum bagi masyarakat sesuai asas kepercayaan yang mendasari weewenang Notaris.

Kedudukan MKN dalam memberikan suatu perlindungan hukum bagi Notaris terhadap akta-akta yang dibuatnya terkait pertanggungjawaban Notaris secara perdata merupakan suatu lembaga yang bersifat independen, karena dalam hal ini keberadaan MKN tidak merupakan sub bagian dari pemerintah yang mengangkatnya. MKN dalam menjalankan kewenangannya mengeluarkan suatu keputusan tidak dipengaruhi oleh pihak atau lembaga lainnya, sehingga dalam hal ini keputusan yang dihasilkan oleh MKN ini tidak dapat diganggu gugat.

Berdasarkan hal-hal diatas maka dapat diketahui bahwa perlindungan hukum bagi Notaris terhadap akta-akta yang dibuatnya terkait pertanggungjawaban Notaris secara perdata ialah pemanggilan Notaris oleh penyidik, penuntut umum dan hakim harus dilakukan dengan mendapatkan persetujuan MKN.

\section{Penutup}

Berdasarkan hasil penelitan dan pembahasan yang telah dikemukakan oleh penulis, maka dapat diambil kesimpulan sebagai berikut: pertama, pertanggungjawaban secara perdata seorang Notaris yang melakukan perbuatan melawan hukum adalah Notaris wajib mempertanggungjawabkan perbuatannya dengan dijatuhi sanksi perdata berupa penggantian biaya atau ganti rugi kepada pihak yang dirugikan atas perbuatan melawan hukum yang dilakukan oleh Notaris. Namun sebelum Notaris dijatuhi sanksi perdata maka Notaris terlebih dahulu harus dapat dibuktikan bahwa telah adanya kerugian yang ditimbulkan dari perbuatan melawan hukum Notaris terhadap para pihak, dan antara kerugian yang diderita dan perbuatan melawan hukum dari Notaris terdapat hubungan kausal, serta perbuatan melawan hukum atau kelalaian tersebut disebabkan kesalahan yang dapat dipertanggungjawabkan kepada Notaris yang bersangkutan. Kedua, bentuk perlindungan hukum bagi Notaris terhadap akta-akta yang dibuatnya terkait pertanggungjawaban Notaris secara perdata adalah adanya Majelis Kehormatan Notaris yang bersifat independen, dalam hal ini keberadaan MKN tidak merupakan sub bagian dari pemerintah yang mengangkatnya. MKN dalam menjalankan kewenangannya mengeluarkan suatu keputusan tidak dipengaruhi oleh pihak atau lembaga lainnya, sehingga dalam hal ini keputusan yang dihasilkan oleh MKN ini tidak dapat diganggu gugat. Peneliti menyarankan, pertama, agar seorang Notaris terhindarkan dari segala resiko baik berupa sanksi maupun 
pembatalan akta otentik dalam proses pembuatan akta yang mengharuskan Notaris bertanggungjawab secara perdata terhadap akta-akta yang dibuatnya, maka Notaris harus menerapkan prinsip kehati-hatian, lebih teliti dan memiliki itikad baik dalam pembuatan akta otentik serta mematuhi ketentuan hukum yang berlaku dan berlandaskan pada moral dan etika. Kedua, keberadaan Majelis Kehormatan Notaris dalam pasal 66 UUJNP diharapkan dibentuk secara berjenjang seperti Majelis Pengawas Notaris, sehingga memungkinkan dalam memberikan upaya hukum banding bagi pihak yang merasa dirugikan (Notaris maupun penyidik) ke tingkat yang lebih tinggi, yaitu melalui MKN Wilayah, maupun MKN Pusat, dengan menempatkan hasil keputusan MKN Daerah sebagai objek pemeriksaan karena hasil keputusan yang dikeluarkan oleh MKN Pusat merupakan keputusan yang bersifat final atau tidak dapat diganggu gugat.

\section{Daftar Pustaka}

\section{Buku/Literatur}

H. Budi Untung, Visi Global Notaris, Andi, Yogyakarta, 2002.

Kartini Soedjendro, Perjanjian Peraihan Hak atas Tanah yang Berpotensi Konflik, Yogyakarta: Kanisius, 2001.

\section{Tesis/Jurnal}

Andi Mamminanga, 2008, Pelaksanaan Kewenangan Majelis Pengawas Notaris Daerah dalam Pelaksanaan Tugas Jabatan Notaris berdasarkan UUJN, Tesis, Fakultas Hukum Universitas Gajah Mada, Yogyakarta.

Christin Sasauw, 2015, Tinjauan Yuridis Tentang Kekuatan Mengikat Suatu Akta Notaris, Jurnal Lex Privatum, Vol.III/No. 1.

Irene Dwi Enggarwati, 2015, Pertanggungjawaban Pidana Dan Perlindungan Hukum Bagi Notaris Yang Diperiksa Oleh Penyidik Dalam Tindak Pidana Keterangan Palsu Pada Akta Otentik, Thesis, Magister Kenotariatan Fakultas Hukum Universitas Brawijaya, Malang.

\section{Peraturan Perundang-undangan}

Kitab Undang-Undang Hukum Perdata.

Undang-Undang Nomor 30 Tahun 2004 Tentang Jabatan Notaris. Lembaran Negara Republik Indonesia Tahun 2004 Nomor 117 dan Tambahan Lembaran Negara Republik Indonesia Nomor 4432.

Undang-Undang Nomor 2 Tahun 2014 Tentang Perubahan Atas Undang-Undang Nomor 30 Tahun 2004 Tentang Jabatan Notaris. Lembaran Negara Republik Indonesia Tahun 2014 Nomor 3 dan Tambahan Lembaran Negara Republik Indonesia Nomor 5491.

Peraturan Menteri Hukum dan Hak Asasi Manusia Republik Indonesia Nomor M.02.PR08.10 Tahun 2004 tentang Tata Cara Pengangkatan Anggota, 
Pemberhentian Anggota, Susunan Organisasi, Tata Kerja dan Tata Cara Pemeriksaan Majelis Pengawas Notaris.

Keputusan Menteri Hukum dan Hak Asasi Manusia Republik Indonesia Nomor: M.39PW.07.10 Tahun 2004 tentang Pedoman Pelaksanaan Tugas Majelis Pengawas Notaris.

Peraturan Menteri Hukum dan Hak Asasi Manusia Republik Indonesia Nomor: M.01HT.03.01 Tahun 2006 tentang Syarat dan Tata Cara Pengangkatan, Pemindahan dan Pemberhentian Notaris. 